\title{
Sustainable Business of Islamic Bank Through on the Islamic Corporate Governance and Islamic Financial Performance
}

\author{
Indra Siswanti ${ }^{1 *}$, Ubud Salim ${ }^{2}$, Eko Ganis Sukoharsono ${ }^{3}$ and Siti Aisjah ${ }^{4}$ \\ ${ }^{1}$ Doctoral Student of Management, Faculty of Economics and Business, University of Brawijaya, 65142, Malang, Indonesia \\ ${ }^{1}$ Faculty of Economics and Business, Perbanas Institute, 12940, Jakarta, Indonesia \\ ${ }^{2,3,4}$ Faculty of Economics and Business, University of Brawijaya, 65142, Malang, Indonesia
}

\begin{abstract}
Objective - The objective of the study is to analyze the application of Islamic Corporate Governance (ICG) on Sustainable Business, focusing on Islamic Financial Performance as a mediating variable in Islamic Banks in Indonesia. Methodology/Technique - The population and sample in the study consists of 9 Islamic Banks. The study uses partial least square (PLS), and the data is collected from public reports for the period between 2010 and 2015. The variables of the study are: Islamic Corporate Governance as an independent variable, Sustainable Business as the dependent variable and Financial Performance as a mediating variable.

Findings - The study shows that Islamic Corporate Governance (ICG) has a positive significant effect on Islamic Financial Performance, Islamic Corporate Governance (ICG) has no effect on Sustainable Business, and Islamic Financial Performance has a positive effect on Sustainable Business. The findings also show that Islamic Financial Performance can have an indirect impact to mediating the effect of Islamic Corporate Governance on Sustainable Business Islamic Bank.

Novelty - Using Murabahah ratio to measure Islamic Financial Performance.

Type of Paper: Empirical.
\end{abstract}

Keywords: Islamic Corporate Governance; Islamic Financial Performance; Sustainable Business. JEL Classification: G21, L22, M41.

\section{Introduction}

In order to face the AEC in Banking 2020, competition in the banking industry will intensify, having an affect on the performance and sustainability of the business of Islamic banks in Indonesia. In the $21^{\text {st }}$ century, the implementation of good corporate governance in the management of banks is very important. Corporate governance in the Islamic perspective is always associated with the concepts related to behaviour in business governance, along with other things that are transcendental to this. This is a direct consequence of a Muslim's to Allah.

\footnotetext{
* Paper Info: Received: November 25, 2016

Accepted: May 4, 2017

* Corresponding author:

E-mail: indrasiswanti3@gmail.com

Affiliation: Management, Perbanas University, Indonesia
} 
Good corporate governance can help create an environment that is conducive to efficient and sustainable growth in all sectors of the company. The importance of corporate governance in Islamic banks is reflected in the results of research conducted by Chapra and Habib (2002) who state that the implementation of corporate governance in some Islamic financial institutions could increase public confidence in Islamic banks. Implementation of corporate governance in Islamic banks is therefore very important. This is because corporate governance not only cultivates the presence of Islamic banks alone, but it also preserves the image or good name of Islamic banks in the eyes of society because there is no guarantee that an institution with the name of sharia certainly is subject to, and complies fully with, the principles of sharia. For that to occur, Islamic banks need to be ensure the existence of good corporate governance structures and processes.

Several studies reveal the importance of corporate governance in relation to the performance of companies (Mohammed \& Fatimoh, 2012; Aggarwal, 2013; Hoque, 2013; Asrori, 2014; Haider et al., 2015). The results of this research states that corporate governance has a positive significant impact on the financial performance of a company.

Financial performance is a useful source of information for investors. One measure of financial performance is profitability. Dilling (2009) states that high profitability and strong long-term growth will affect the sustainability of a company's business. Nawaiseh (2015) also states that financial performance is given proxies by the ROA and ROE which have a positive significant impact on the disclosure of Corporate Social Responsibility (CSR).

Sustainability is the balance between people-planet-profit, known as the concept of the triple bottom line (TBL). Sustainability lies at the confluence of three aspects: people-society; planet-environment; and profiteconomic (Elkington, 1998). The implementation of sustainable business practices can be achieved through the adoption of CSR measures. CSR, from an Islam perspective, must reflect the principles of Islam in the public interest as Islamic banks not only focus on making a profit, but also on social welfare and protection needs (Dusuki \& Abdullah, 2005).

There are inconsistent results concerning the impact of corporate governance on the sustainability of businesses. For example, research conducted by Sari and Marsono (2013), Janggu et al. (2014), and Hashim et al. (2015) all state that corporate governance has a significant influence and positive impact on the sustainability of businesses. This is in contrast with research by Aras and Crowther (2008), Aziz (2014) and Hashim et al. (2015) which all states that corporate governance does not affect the disclosure quality of a company's sustainability report.

Corporate governance is also considered to be a variable that can affect the sustainability of a company (Hashim et al., 2015). In general, financial performance is measured by the level of profitability. Hameed et al. (2004) measured the financial performance of Islamic banks using the Profit Sharing Ratio (PSR) and Zakat Performance Ratio (ZPR). In the present study, the murabaha ratio will be used to measure the performance of Islamic financial institutions. Murabahah ratio has never been used by Islamic banks to measure financial performance.

\section{Literature Review}

Accord Bhatti and Bhatti, Islamic corporate governance is defined as follows:

"Islamic corporate governance (ICG) seeks to devise ways in which economic agents, the legal system, and corporate governance can be by moral and social values based on Shari'ah laws. Its supporters believe that all economic, corporate, and business activities should be based on an ethareligious paradigm, with the sole aim being the welfare of individuals and society as a whole. In many ways, ICG propose its objective as conventional corporate governance, but within the religious-based moral codes of Islam. A model of ICG may be proposed by recording the objectives of Sharia'ah with the stakeholder model of corporate governance". 
Financial performance refers to the company's financial condition at a given period and concerns aspects of fundraising and distribution of funds, which is usually measured by indicators of capital adequacy, liquidity, and profitability (Jumingan, 2006). This study builds on the results of research conducted by Hammed et al. (2004). Thus, in this study, murabaha ratios are used to assess the financial performance of Islamic banks.

The definition of sustainable business is the ability of a company to achieve business objectives and improve the long-term value for shareholders by integrating economic, social and environmental factors into its business strategy (Wibisono, 2007). Sustainability is the balance between people-planet-profit, known as the concept of the triple bottom line (TBL). Sustainability lies at the confluence of three aspects: people-socially; planetenvironment; and profit-economic (Elkington, 1998).

The main objective of research is to examine the sustainability of the business of Islamic banks, focusing on Islamic corporate governance and Islamic financial performance.

\section{Methodology}

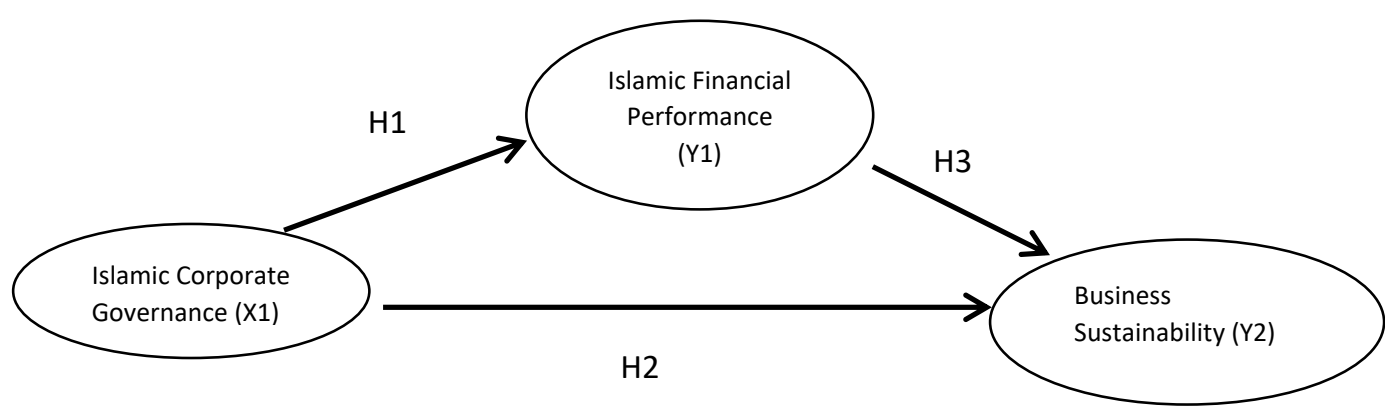

Figure 1. Empirical Research Model

Research hypotheses are as following:

- $\mathrm{H}_{1}$ : The improvement of Islamic corporate governance will improve Islamic financial performance.

- $\mathrm{H}_{2}$ : The improvement of Islamic corporate governance will increase the sustainability of the business.

- $\mathrm{H}_{3}$ : The improvement of Islamic financial performance will increase the sustainability of the business.

- $\mathrm{H}_{4}$ : Islamic financial performance is a mediator of Islamic corporate governance which will increase the sustainability of the business.

As regards to research methodology, population in this study consists of 9 Islamic commercial banks. Samples are taken with the saturated sampling method. By using the entirety of available Islamic banks, the sample used includes 9 Islamic commercial banks. They are: Bank Muamalat, Bank Syariah Mandiri, Bank Mega Syariah, Bank BRI Syariah, Bank BNI Syariah, Bank Syariah Bukopin, Bank BCA Syariah, Bank Panin Syariah and Bank Panin Syariah.

To analyze the data, the study uses analytical techniques such as the Partial Least Square (PLS). The stages in testing PLS include: designing structural models (inner model), designing measurement models (outer model), constructing a path diagram, and testing the fitness of the structural model and the hypotheses.

\section{Result and Discussion}

\subsection{Testing the Fitness of the Structural Model (Inner Model)}

Testing the fit of the structural model (inner model) is achieved by looking at R2 from the latent variables with Geisser Q Square test. Based on the calculations, the predictive value of the Q-square-relevance (Q2) is $81.9 \%$. These values indicate that the sustainability of Islamic banks is influenced by Islamic corporate governance and Islamic financial performance, which amounts to $81.9 \%$. The remaining $18.1 \%$ is a result of other variables that have not been used in this study. 
Table 1. Recapitulation Results

\begin{tabular}{|c|c|c|c|c|}
\hline $\begin{array}{c}\text { Impact between } \\
\text { variables }\end{array}$ & Path Coefficient & T-Statistics & P-Value & Information \\
\hline $\mathrm{X}_{1} \rightarrow \mathrm{Y}_{1}$ & 0.4493 & 3.2664 & 0.001 & Significant \\
\hline $\mathrm{X}_{1} \rightarrow \mathrm{Y}_{2}$ & 0.1103 & 0.7914 & 0.429 & No Significant \\
\hline $\mathrm{Y}_{1} \rightarrow \mathrm{Y}_{2}$ & 0.2695 & 2.1109 & 0.035 & Significant \\
\hline
\end{tabular}

\subsection{The Effect of Islamic Corporate Governance on Islamic Financial Performance}

The results of the statistical analysis generated a path coefficient value of 0.4493 and a t-statistic value of 3.2664 , which is greater than t-table (3.2664> 1.960) with a p-value of 0.001 . These results suggest that Islamic corporate governance has a positive significant effect on Islamic financial performance. This means that the implementation of Islamic corporate governance is able to improve the Islamic financial performance of Islamic banks. The results of this study are consistent with the results of research conducted previously such as: Mohammed and Fatimoh (2012); Aggarwal (2013); Hoque et al. (2013); Asrori (2014) and Haider et al. (2015). This previous research all state that good corporate governance has a positive significant impact on the financial performance of a company. It can be concluded that Islamic corporate governance is able to increase Islamic financial performance, therefore that hypothesis is accepted.

\subsection{The Effect of Islamic Corporate Governance on the Sustainability of a Business}

The test of the effect of Islamic Corporate Governance on Sustainable Business generates a path coefficient value of 0.1103 and a t-statistic value of 0.7914 , which is smaller than t-table $(0.7914<1.960)$ with a p-value of 0.429 . The results suggest that Islamic corporate governance does not effect the sustainability of a business. This is because the outer loading value is 3 being the 3 indicators of Islamic corporate governance, including: indicator completeness and implementation of committee assignments (X1.3) has a value of outer loading 0.8153; indicators of performance of duties and responsibilities of the Sharia Supervisory Board (X1.4) has a value of outer loading 0.7942; and indicator handling of conflicts of interest (X1.6) has a value of outer loading 0.8292 . The three indicators therefore have outer loading values below the average value of outer loading $(<0.9135)$. Therefore, all three indicators influence the effect of Islamic Corporate Governance on the sustainability of a business, which becomes insignificant. The results suggest that Islamic banks should pay more attention to the three indicators, so that if all the indicators of Islamic corporate governance are running at optimal levels, it may enhance the sustainability of their business.

These results are consistent with research conducted by Aras and Crowther (2008) and Aziz (2014), which both state that it is not enough to prove that good corporate governance will ensure that a company will be sustainable. It can be concluded that Islamic corporate governance does not necessarily guarantee the sustainability of a business, therefore that hypothesis is not accepted.

\subsection{The Effect of Islamic Financial Performance on the Sustainability of a Business.}

In testing the effect of Islamic Financial Performance on the sustainability of a business, the result generates a path coefficient value of 0.2695 and a t-statistic value of 2.1109 , which is greater than t-table $(2.1109>1.960)$ with a p-value of 0.035 . These results indicate that Islamic financial performance has a significant positive effect on the sustainability of a business. This means that Islamic financial performance will improve the sustainability of Islamic bank. Thus, it can be said that good Islamic financial performance will increase the company's level of corporate social responsibility which in turn will be able to improve the welfare of the 
community. Dilling (2009) states that high profitability and strong long-term growth will affect the sustainability of a business. These results are consistent with research conducted by Nawaiseh (2015), which states that a company's financial performance has a significantly positive effect on the disclosure of CSR, which in turn will improve the welfare of the community. It can be concluded that Islamic financial performance is able to improve the sustainability of a business, therefore that hypothesis is accepted.

\subsection{Islamic Financial Performance as a Mediator of the Effect of Islamic Corporate Governance on the Sustainability of a Business.}

Table 2. Testing Model Mediation (Indirect Impact)

\begin{tabular}{|c|c|c|c|c|}
\hline $\begin{array}{c}\text { Indirect } \\
\text { Impact }\end{array}$ & \multicolumn{2}{|c|}{ Coefficient Direct Impact } & $\begin{array}{c}\text { Coefficient } \\
\text { Indirect Impact }\end{array}$ & Information \\
\hline $\mathrm{X}_{1} \rightarrow \mathrm{Y}_{1} \rightarrow \mathrm{Y}_{2}$ & $\mathrm{X}_{1} \rightarrow \mathrm{Y}_{1}=0.449$ & $\mathrm{Y}_{1} \rightarrow \mathrm{Y}_{2}=0.270$ & 3.698 & $\begin{array}{c}\text { Full Mediation } \\
\text { (Sobel Test) }\end{array}$ \\
\hline
\end{tabular}

The results of the analysis of the indirect impact of Islamic corporate governance on the sustainability o a business through Islamic financial performance has a significant positive coefficient value of 3.698, meaning that Islamic corporate governance has an impact on sustainable business performance through Islamic financial performance. This study therefore suggests that the sustainability of an Islamic bank can be achieved indirectly through the influence of Islamic financial performance and Islamic corporate governance. The path coefficients of the influence of Islamic corporate governance on the sustainability of a business amounted to 0.110 (not significant), the path coefficient of the influence of Islamic corporate governance on Islamic financial performance is 0.449 (significant) and the path coefficient of the influence of Islamic financial performance on the sustainability of a business amounted to 0.269 (significant). This study therefore shows that Islamic financial performance is a complete mediator of the effect of Islamic corporate governance on the sustainability of Islamic banks.

\section{Conclusion}

The improvement of Islamic corporate governance was not proven to improve the sustainability of a business. This finding suggests that, although Islamic corporate governance has been implemented, it does not guarantee the sustainability of Islamic banks. However, Islamic banks must maintain and enhance Islamic corporate governance because implementation of Islamic corporate governance will have a positive impact on improving Islamic financial performance, which will ultimately have a positive impact on the improvement of the sustainability of Islamic banks.

\section{References}

Aggarwal, P (2013). Impact of Corporate Governance on Corporate Financial Performance. IOSR Journal of Business and Management (IOSR-JBM), 13(3), 01-05.

Aras, G., \& Crowther, D. (2008). Governance and sustainability: An investigation into the relationship between corporate governance and corporate sustainability. Management Decision, 46(3), 433-448.

Asrori (2014). Implementasi Islamic Corporate Governance dan Implikasinya Terhadap Kinerja Bank Syariah (Implementation of Islamic Corporate Governance and its Implication on Islamic Bank Performance), Jurnal Dinamika Akuntansi, 6(1), 90-102

Azis, A (2014). Analisis Pengaruh Good Corporate Governance terhadap Sustainability Report [Analysis on the Impact of Good Corporate Governance on Sustainability Report], Jurnal Audit dan Akuntansi Fakultas Ekonomi Univ. Tanjungpura, 3(2), 65-84

Bhatti \& Bhatti (2010). Toward Understanding Islamic Corporate issues in Islamic Finance. Asian politics and Policy, 2(2), 25-38 
Chapra \& Habib. (2002). Islamic Governance: In Islamic Financial Institutions, Islamic Development Bank (IDB), Islamic Research Training Islamic Institute (IRTI), (Jeddah: King Fahd National Cataloging-in-Publication Data, 2002), 121-123

Dilling (2009). Sustainability Reporting In A Global Context : What Are The Characteristics of Corporations That Provide High Quality Sustainability Reports - An Empirical Analysis. International Business \& Economics Research Journal. 9(1).

Dusuki, A. W., \& Abdullah, N. I. (2007). Maqasid al-shari'ah, Maslahah and corporate social responsibility. The American Journal of Islamic Social Sciences (AJISS), 24(1), 25-45.

Elkington, J. (1998). Cannibals with Forks: The Triple Bottom Line of 21st Century Business, Gabriola Island, New Society Publishers

Haider, K. \& Iqbal (2015). Impact of corporate Governance on Firm Financial Performance in Islamic Financial Institution.International Letters of Social and Humanistic Sciences. 51, 106-110.

Hameed, W., AlRazi, N., \& Pramono (2004). Alternative Disclosure dan Performance for Islamic Banks. Proceeding of The Second Conference on Administrative Science: Meeting The Challenges of The Globalization Age. Dahran, Saud Arabia

Hashim, F., Mahadi, N. D., \& Amran, A. (2015). Corporate Governance and Sustainability Practices in Islamic Financial Institutions: The Role of Country of Origin. Procedia Economics and Finance, 31, 36-43.

Hoque, I. \& Ahmed (2013). Corporate Governance and Bank Performance: The Case of Bangladesh. Social Science Electronic Publishing.

Janggu, T., Darus, F., Zain, M. M., \& Sawani, Y. (2014). Does good corporate governance lead to better sustainability reporting? An analysis using structural equation modeling. Procedia-Social and Behavioral Sciences, 145, 138145.

Jumingan (2006). Analisis Laporan Keuangan (Financial Report Analysis), Cetakan Pertama, PT Bumi Aksara, Jakarta

Mohammed \& Fatimoh. (2012). Impact of Corporate Governance on Banks Performance in Nigeria. Journal of Emerging Trends in Economics and Management Sciences (JETEMS). 3(3), 257-260

Nawaiseh, M. (2015). Do Firm Size and Financial Performance Affect Corporate Social Responsibility Disclosure: Employees' and Environmental Dimensions? American Journal of Applied Sciences. 12(12), 967-981

Sari \& Marsono (2013). Pengaruh Kinerja Keuangan, Ukuran Perusahaan dan Corporate Governance Terhadap Pengungkapan Sustainability Report [The Impact of Financial Performance, Company Size, and Corporate Governance on Sustainability Report Disclosure]. Diponegoro Journal Of Accounting, 2(3), 1-10.

Wibisono, Y. (2007), Membedah Konsep \& Aplikasi CSR [Explicating the Concept \& Application of CSR) (Corporate Social Responsibility], Gresik : Fascho Publishing, 2007 